I N S T I T U T O

DE

M E D I C I N A

T R O P I C A L

$\mathrm{DE}$

S ÃO PAULO

JOURNAL OF THE SÃO PAULO INSTITUTE OF TROPICAL MEDICINE

${ }^{1}$ Hospital Doutor Arnaldo Pezzuti Cavalcanti, Departamento de Medicina Intensiva, Mogi das Cruzes, São Paulo, Brazil

2Universidade de Mogi das Cruzes, Mogi das Cruzes, São Paulo, Brazil

${ }^{3}$ Universidade Estadual de Londrina, Londrina, Paraná, Brazil

Correspondence to: Diego Moreno Watashi

Universidade de Mogi das Cruzes, Av. Dr. Cândido Xavier de Almeida e Souza, 200, CEP 08780-911, Mogi das Cruzes, SP, Brazil

Tel: +55 11 98414-3888

E-mail: diegowatashi@ hotmail.com

Received: 30 June 2021

Accepted: 12 July 2021

\section{COVID-19 presenting as persistent hiccups: a case report}

\author{
Diogo Ribeiro de Sene ${ }^{(1)}$, Diego Moreno Watashi ${ }^{(12}$, Isabella de Oliveira \\ Bilitardo ${ }^{\circledR}$, Carlos Eduardo Campos Moreno ${ }^{\circledR}$, Mariella Freire de Freitas \\ Moreno ${ }^{\circledR 3}$
}

\section{ABSTRACT}

Hiccups are involuntary, spasmodic contractions of the diaphragm and intercostal muscles and can be classified as acute $(<48 \mathrm{~h})$, persistent ( $48 \mathrm{~h}$ to a month) or intractable (>1 month). A previously healthy 29-year-old man sought the Emergency Department with flu-like symptoms and a two-day history of persistent hiccups. His physical examination was otherwise unremarkable and vital signs were within normal limits. An unenhanced computed tomography scan of the chest showed small focal ground-glass opacities scattered throughout $25 \%$ of the lungs. A COVID-19 test was positive. Chlorpromazine was prescribed for the hiccups with improvement over $10 \mathrm{~h}$. The patient was discharged home on the same day without hiccups and no other complications.

KEYWORDS: COVID-19. Hiccups. SARS-CoV-2. Chlorpromazine. Atypical presentation.

\section{INTRODUCTION}

Hiccups are diaphragmatic and intercostal muscle contractions with early glottis closure terminating the inspiration. They are involuntary and spasmodic, and are controlled by a complex reflex arc between peripheral receptors and the brainstem. Any disruption along this pathway may produce hiccups. Hiccups can be classified as acute $(<48 \mathrm{~h})$, persistent ( $48 \mathrm{~h}$ to a month) or intractable ( $>1 \mathrm{month})$. Most acute hiccups are transient, benign and self-limited. However, persistent and intractable hiccups may be considered a sign of underlying pathology and although the most common cause is gastroesophageal reflux disease (GERD), atypical causes as COVID-19 are now identified in rare reports in the literature ${ }^{1,2}$.

\section{CASE REPORT}

A 29-year old man sought the Emergency Department complaining of hiccups in the last 2 days. The patient reported one febrile episode of $37.8^{\circ} \mathrm{C}$ which improved after the use of acetaminophen, and a 3-day history of cough, rhinorrhea and mild shortness of breathe. Upon admission, he denied feeling tightness in his chest or a sore throat. The patient had no previous history of chronic diseases or allergies and denied abuse of alcohol, other drugs and was not a smoker. His blood pressure was $132 / 74 \mathrm{cmHg}$, the respiratory rate was 20 breaths/min, his heart rate was 73 beats/min and regular, the body temperature was $36.4{ }^{\circ} \mathrm{C}$ and the oxygen saturation was $94 \%$ in room air. There were bilateral scattered crackles during the auscultation of the lungs and no signs of respiratory insufficiency. The head and the neurological examination were normal. Routine blood test results were as 
follows: red blood cells $4.74 \times 10^{6}$ cells/uL; white blood cells $7.75 \times 10^{3}$ cells/uL; neutrophils $81.2 \%$; lymphocytes $13.4 \%$; total number of lymphocytes $1.039 \times 10^{3}$ cells/uL; platelets $194 \times 10^{3}$ cells/uL; C-reactive protein (CRP) $32 \mathrm{mg} / \mathrm{L}$; potassium $4.2 \mathrm{mEq} / \mathrm{L}$; sodium $137 \mathrm{mEq} / \mathrm{L} ;$ BUN $15.4 \mathrm{mg} / \mathrm{dL}$; serum creatinine $(\mathrm{Cr}) 1.04 \mathrm{mg} / \mathrm{dL}$; D-dimer $142 \mathrm{ng} / \mathrm{mL}$; lactate dehydrogenase (LDH) $179 \mathrm{U} / \mathrm{L}$; ferritin $245 \mathrm{ng} / \mathrm{mL}$; troponin $1.4 \mathrm{pg} / \mathrm{mL}$. His arterial blood gas analysis was as follows: $\mathrm{pH} 7.41 ; \mathrm{pCO}_{2} 36 \mathrm{mmHg}$; $\mathrm{pO}_{2} 83 \mathrm{mmHg}$; Oxygen saturation $96 \% ; \mathrm{HCO}_{3} 22.8 \mathrm{mEq} / \mathrm{L}$; Base excess $-2.1 \mathrm{mEq} / \mathrm{L}$.

The chest computed tomography (CT) was performed and small subpleural ground-glass opacities, as well as small sparse areas of atelectasis were observed scattered across the two lungs and affecting less than $25 \%$ of lung parenchyma, suggesting the presence of a viral pneumonia (Figure 1). A real-time reverse transcription-polymerase chain reaction (RT-PCR) analysis of the patient's throat swab sample confirmed the SARS-Cov-2 infection. The Valsalva maneuver used in an attempt to stop the hiccups was unsuccessful. As the patient did not meet the Centers for Disease Control and Prevention (CDC) established criteria for COVID-19 severe illness, he was discharged home with symptomatic medication ${ }^{3}$. The patient was followed-up by phone for 10 days and treated with chlorpromazine for the resistant hiccups, which disappeared $10 \mathrm{~h}$ after starting treatment. The chlorpromazine treatment was continued for three days, for a total of five days, and there was no relapse after treatment discontinuation.

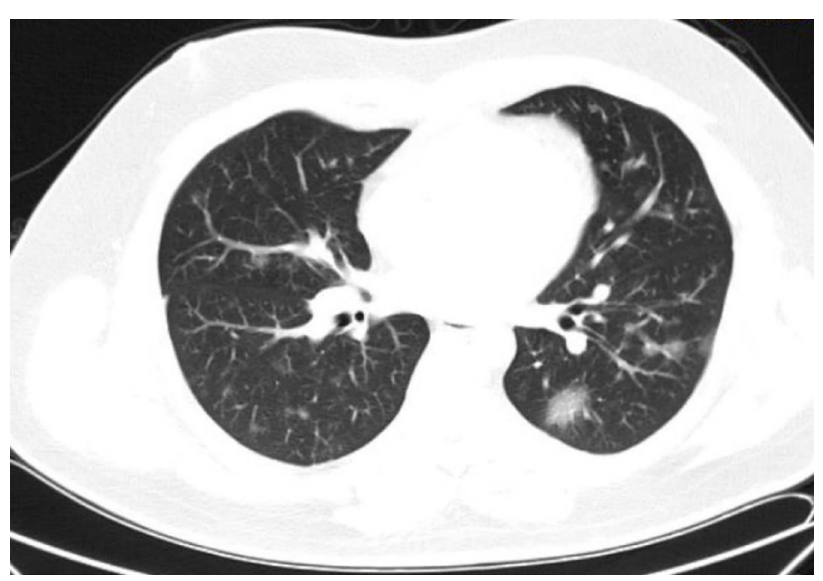

Figure 1 - A chest computed tomography scan showing peripheral ground-glass opacities in lungs.

\section{DISCUSSION}

Since the first COVID-19 report, clinical manifestations were described in most cases as fever, nonproductive cough, dyspnea, myalgia, fatigue, normal or decreased leukocyte count, in addition to radiographic evidence of pneumonia in the chest $\mathrm{CT}$ scan.

The severe presentation of COVID-19 included organ dysfunction, clinically presenting as shock, acute respiratory distress syndrome (ARDS), acute cardiac injury, acute kidney injury and death ${ }^{4}$. However, with the growing COVID-19 data around the world, different presentations have been reported, highlighting the clinical heterogeneity of this disease. This case reports a patient with an atypical presentation: persistent hiccups ${ }^{5}$.

The correlation between COVID-19 and hiccups still remains unclear, but other infectious conditions such as influenza, herpes zoster, neurosyphilis and tuberculosis have been related to hiccups ${ }^{6,7}$.

The severity and treatment of hiccups depend on their temporal classification. Acute hiccups are usually benign and self-limited, not requiring intervention or etiological investigation in the majority of cases. However, patients whose hiccups interfere with their quality of life may attempt physical maneuvers to relieve their symptoms. These maneuvers are harmless to the patient and they work by increasing the vagal stimulus, interrupting the normal respiratory rhythm an the nasopharynx stimulus. There are several methods: breath holding, Valsalva's maneuver, eyeball compression, drinking cold water, pulling out the tongue, among others ${ }^{6,8}$.

Persistent hiccups usually interfere with the patient's daily activities and they often hide a pathological etiology, therefore the underlying cause should be investigated. Some common causes are gastroesophageal reflux (GERD), malignancies, myocardial infarction, cerebrovascular diseases, medications, toxic metabolites, infectious agents, among others. Physical maneuvers may be initially attempted in order to relieve the symptoms, but in contrast to acute hiccups, persistent and intractable hiccups are less likely to be terminated by physical therapy.

The treatment should always be focused on the underlying cause, but an empiric treatment can be used while the etiology is under investigation. The first empiric option should be a proton pump inhibitor, as the most common cause of persistent hiccups is GERD. In the absence of symptoms improvement or the diagnosis of a serious etiology, a wide variety of medications can be used. The most common options are baclofen, gabapentin, metoclopramide and chlorpromazine ${ }^{6}$. In our case, chlorpromazine was used as the first option due to the drug availability. Similar case reports of COVID-19 associated with hiccups are presented in Table 1. Briefly, including the case reported here, there are 10 cases of COVID-19 (confirmed by RT-PCR) associated with hiccups in the literature, all of them in male patients aged 29-68 years, 
Table 1 - Similar case reports of COVID-19 associated with hiccups.

\begin{tabular}{|c|c|c|c|c|c|}
\hline & $\begin{array}{c}\text { Gender and age } \\
\text { of the patient } \\
\text { (years) }\end{array}$ & Presentation & Laboratory tests and imaging & Treatment & Outcome \\
\hline Our case & $\begin{array}{l}\text { Male } \\
29\end{array}$ & $\begin{array}{l}\text { Persistent hiccups } \\
\text { Two-day history }\end{array}$ & $\begin{array}{l}\text { Chest CT scan with ground- } \\
\text { glass opacities and small } \\
\text { sparse areas of atelectasis } \\
\text { Positive RT-PCR for } \\
\text { SARS-CoV-2 }\end{array}$ & Chlorpromazine & $\begin{array}{c}\text { Symptoms improved } \\
\text { after } 10 \mathrm{~h}\end{array}$ \\
\hline $\begin{array}{l}\text { Dorgalaleh } \\
\text { et al. }{ }^{9}\end{array}$ & $\begin{array}{l}\text { Male } \\
52\end{array}$ & Persistent hiccups & $\begin{array}{l}\text { Chest CT scan with ground- } \\
\text { glass in the left lower lobe } \\
\text { Positive RT-PCR for } \\
\text { SARS-CoV-2 }\end{array}$ & $\begin{array}{l}\text { Metoclopramide } \\
\text { Chlorpromazine }\end{array}$ & $\begin{array}{c}\text { Symptoms improved } \\
\text { after } 5 \text { days }\end{array}$ \\
\hline \multirow{2}{*}{$\begin{array}{l}\text { Ikitimur } \\
\text { et } a l . .^{10}\end{array}$} & $\begin{array}{l}\text { Male } \\
60\end{array}$ & $\begin{array}{l}\text { Persistent hiccups } \\
\text { Three-day history }\end{array}$ & $\begin{array}{c}\text { Chest CT scan with ground- } \\
\text { glass in the left lower lobe } \\
\text { Positive RT-PCR for } \\
\text { SARS-CoV-2 }\end{array}$ & Chlorpromazine & $\begin{array}{c}\text { Symptoms improved } \\
\text { after } 12 \mathrm{~h}\end{array}$ \\
\hline & $\begin{array}{c}\text { Male } \\
68\end{array}$ & Persistent hiccups & $\begin{array}{l}\text { Chest CT scan with ground- } \\
\text { glass in the left lower lobe } \\
\text { Positive RT-PCR for } \\
\text { SARS-CoV-2 }\end{array}$ & Chlorpromazine & $\begin{array}{c}\text { Symptoms improved } \\
\text { after } 3 \text { days }\end{array}$ \\
\hline $\begin{array}{l}\text { Prince and } \\
\text { Serge }^{5}\end{array}$ & $\begin{array}{l}\text { Male } \\
62\end{array}$ & $\begin{array}{l}\text { Persistent hiccups } \\
\text { Four-day history }\end{array}$ & $\begin{array}{l}\text { Chest CT scan with ground- } \\
\text { glass opacities } \\
\text { Positive RT-PCR for } \\
\text { SARS-CoV-2 }\end{array}$ & None & Symptoms improved \\
\hline $\begin{array}{l}\text { Bakheet } \\
\text { et al. }{ }^{11}\end{array}$ & $\begin{array}{l}\text { Male } \\
48\end{array}$ & $\begin{array}{l}\text { Persistent hiccups } \\
\text { Seven-day history }\end{array}$ & $\begin{array}{l}\text { Chest CT scan with ground- } \\
\text { glass opacities } \\
\text { Positive RT-PCR for } \\
\text { SARS-CoV-2 }\end{array}$ & Baclofen & Symptoms improved \\
\hline $\begin{array}{l}\text { Alvarez- } \\
\text { Cisneros } \\
\text { et al. }{ }^{12}\end{array}$ & $\begin{array}{l}\text { Male } \\
48\end{array}$ & $\begin{array}{l}\text { Persistent hiccups } \\
\text { Four-day history }\end{array}$ & $\begin{array}{l}\text { Chest CT scan with ground- } \\
\text { glass opacities } \\
\text { Positive RT-PCR for } \\
\text { SARS-CoV-2 }\end{array}$ & $\begin{array}{l}\text { Metoclopramide, } \\
\text { omeprazol, } \\
\text { ondanseteon } \\
\text { and oral frappe } \\
\text { megaldrate/ } \\
\text { dimeticone } \\
\end{array}$ & $\begin{array}{l}\text { No improvement } \\
\text { Patient refused } \\
\text { hospital admission } \\
\text { and was lost to } \\
\text { follow-up }\end{array}$ \\
\hline $\begin{array}{l}\text { Totomoch- } \\
\text { Serra et al. }{ }^{13}\end{array}$ & $\begin{array}{l}\text { Male } \\
60\end{array}$ & Persistent hiccups & $\begin{array}{l}\text { Chest X-ray showing lung } \\
\text { parenchyma with decreased } \\
\text { radiolucency of images with } \\
\text { poorly defined irregular edges }\end{array}$ & $\begin{array}{l}\text { Clonazepam } \\
\text { Haloperidol }\end{array}$ & $\begin{array}{c}\text { Symptoms improved } \\
\text { after } 3 \text { days }\end{array}$ \\
\hline $\begin{array}{l}\text { Sangamesh } \\
\text { et al. }{ }^{14}\end{array}$ & $\begin{array}{l}\text { Male } \\
72\end{array}$ & $\begin{array}{l}\text { Persistent hiccups } \\
\text { Five-day history }\end{array}$ & $\begin{array}{c}\text { Chest X-ray with bilateral lower } \\
\text { lobe infiltrates } \\
\text { Positive RT-PCR for } \\
\text { SARS-CoV-2 } \\
\end{array}$ & Baclofen & $\begin{array}{c}\text { Symptoms improved } \\
\text { after } 2 \text { days }\end{array}$ \\
\hline Atiyat et al. ${ }^{15}$ & $\begin{array}{c}\text { Male } \\
61\end{array}$ & $\begin{array}{l}\text { Persistent hiccups } \\
\text { Two-day history }\end{array}$ & $\begin{array}{c}\text { Chest X-ray with bilateral } \\
\text { middle lung opacities } \\
\text { Positive RT-PCR for } \\
\text { SARS-CoV-2 } \\
\end{array}$ & Metoclopramide & - \\
\hline $\begin{array}{l}\text { Chiquete } \\
\text { et al. }{ }^{16}\end{array}$ & $\begin{array}{l}\text { Male } \\
62\end{array}$ & $\begin{array}{l}\text { Persistent hiccups } \\
\text { Five-day history }\end{array}$ & $\begin{array}{l}\text { Chest CT scan with viral } \\
\text { pneumonia } \\
\text { Positive RT-PCR for } \\
\text { SARS-CoV-2 }\end{array}$ & $\begin{array}{l}\text { Levomepromazine } \\
\text { Levosulpiride }\end{array}$ & $\begin{array}{c}\text { Symptoms improved } \\
\text { after } 3 \text { days }\end{array}$ \\
\hline
\end{tabular}

RT-PCR $=$ real-time reverse transcription-polymerase chain reaction

with abnormal chest CT scan or chest X-rays of the lungs, all patients but one received medications to stop the hiccups, and according to the follow-up description, eight patients evolved with improvement of symptoms, including ours, one case was lost to follow-up, and in one case data were not available in the medical record.

\section{CONCLUSION}

During the COVID-19 pandemic, health care workers must maintain a high clinical suspicion of COVID-19 examining patients with atypical presentations of this disease, such as persistent hiccups. 


\section{REFERENCES}

1. Woelk CJ. Managing hiccups. Can Fam Physician. 2011;57:6725,e198-201.

2. Reichenbach ZW, Piech GM, Malik Z. Chronic hiccups. Curr Treat Options Gastroenterol. 2020 In Press.

3. Centers for Disease Control and Prevention. Interim clinical guidance for management of patients with confirmed Coronavirus disease (COVID-19). [cited 2021 Jul 12]. Available from: https://www.cdc.gov/coronavirus/2019-ncov/ hcp/clinical-guidance-management-patients.html

4. Huang C, Wang Y, Li X, Ren L, Zhao J, Hu Y, et al. Clinical features of patients infected with 2019 novel coronavirus in Wuhan, China. Lancet. 2020;395:497-506.

5. Prince G, Sergel M. Persistent hiccups as an atypical presenting complaint of COVID-19. Am J Emerg Med. 2020;38:1546. e5-6.

6. Jeon YS, Kearney AM, Baker PG. Management of hiccups in palliative care patients. BMJ Support Palliat Care. 2018;8:1-6.

7. Cole JA, Plewa MC. Singultus. Treasure Island: StatPearls; 2021.

8. Steger M, Schneemann M, Fox M. Systemic review: the pathogenesis and pharmacological treatment of hiccups. Aliment Pharmacol Ther. 2015;42:1037-50.

9. Dorgalaleh A, Dabbagh A, Tabibian S, Bahraini M, Rafieemehr H. Persistent hiccups in a patient with mild congenital factor V deficiency and COVID-19; clinical and laboratory finding of a rare bleeding disorder. Int J Lab Hematol. 2021;43:e87-8.

10. Ikitimur H, Borku Uysal B, Ikitimur B, Umihanic S, Smajic J, Jahic R, et al. Two cases of persistent hiccups complicating COVID-19. Am J Trop Med Hyg. 2021;104:1713-5.

11. Bakheet N, Fouad R, Kassem AM, Hussin W, El-Shazly M. Persistent hiccup: a rare presentation of COVID-19. Respir Investig. 2021;59:263-5.

12. Alvarez-Cisneros T, Lara-Reyes A, Sansón-Tinoco S. Hiccups and psychosis: two atypical presentations of COVID-19. Int J Emerg Med. 2021;14:8.

13. Totomoch-Serra A, Ibarra-Miramon CB, Manterola C. Persistent hiccups as main COVID-19 symptom. Am J Med Sci. 2021;361:799-800.

14. Sangamesh S, Gosavi S, Shastry S, Johny SM. Hiccups and hyponatremia: unusual co-presentation in COVID-19. J Family Med Prim Care. 2021;10:1040-3.

15. Atiyat R, Veeraballi S, Al-Atiyat N, Chan KH, Slim J. A rare case report of persistent hiccups as an atypical presentation of COVID-19. Cureus. 2021;13:e13625.

16. Chiquete E, Toapanta-Yanchapaxi L, Aceves-Buendía JJ, Ruiz-Ruiz E, Rodríguez-Perea E, Durán-Coyote S, et al. Levosulpiride relieved persistent hiccups in a patient With COVID-19 and vascular cognitive impairment. Clin Neuropharmacol. 2021 In Press.

\section{ERRATUM}

On page 1, third paragraph, $2^{\text {nd }}$ line:

Where it reads:

"in the last 2 days"

Should be read:

"for the last 2 days"

On page 1, third paragraph, $4^{\text {th }}$ line:

Where it reads:

"shortness of breathe"

Should be read:

"shortness of breath"

On page 1, third paragraph, $6^{\text {th }}$ line:

Where it reads:

"abuse of alcohol, other drugs"

Should be read:

"abuse of alcohol or other drugs"

On page 1 , third paragraph, $7^{\text {th }}$ line:

Where it reads:

"cmHg"

Should be read:

"mmHg"

On page 1, third paragraph, $9^{\text {th }}$ line:

Where it reads:

"in room air"

Should be read:

"on room air"

On page 2, eighth paragraph, $9^{\text {th }}$ line:

Where it reads:

"normal respiratory rhythm an the nasopharynx stimulus"

Should be read:

"normal respiratory rhythm and the nasopharynx stimulus"

http://dx.doi.org/10.1590/s1678-9946202163062err 